\title{
Determinants of Loan Repayment Performance in Shashemene City Administration: (The Case of Oromia Credit and Saving Share Company in Shashemene Branch, Oromia Region, Ethiopia)
}

\author{
Fikadu Tulu \\ Bule Hora University \\ Debeli Chala \\ Ethiopian Biodiversity Institute
}

\begin{abstract}
Microfinance can be an important element of an effective poverty reduction strategy especially for developing countries. In Ethiopia, there has been a high growing interest in considering micro financing as an important approach for the poor. The services provided by microfinance institutions is needed to enable the poor to reduce their consumption, manage their risks better, build their assets gradually, develop their micro enterprises, improve their income earning capacity, and enjoy an improved quality of life. However, the performance of loan repayment has become a serious problem in the country in general and in the study area in particular. This study was therefore identifying and analyzing the determinants of LRP in MFIs with particular reference to OCSSCO Shashamene branch. A total of 169 respondents were included in the survey and the main data for the study was collected through structured questionnaire administered by trained enumerators. In addition, secondary data was collected from the branch office records. Probit model was employed to analyze the determinants of loan repayment performance of the branch borrowers. A total of sixteen explanatory variables were included in the model's equation. The result of probit regression confirmed that nine of them; age of the borrowers, level of education, income from activities financed by the loan, suitability of , family size, loan diversion rate, residential area, loan size and grace period were significantly affect LRP while the remaining were found to be insignificant in the model. STATA14.0 software was used to analyze data and t-test and chi-squared test was employed to compare nondefaulters and defaulters with respect to significant explanatory variables. Hence, taking these factors in to account is vital since it provides information enabling to take effective measures aiming at improving LRP in the study area. Equivalently, it would also help the institution and policy makers by providing information on how to exercise their capacity to reduce loan default.
\end{abstract}

Keywords: Micro-finance, loan repayment performance, Probit model, Credit and Saving Share Company, Shashemene City.

DOI: $10.7176 / \mathrm{JESD} / 10-19-04$

Publication date:October $31^{\text {st }} 2019$

\section{Back ground of the study}

Ethiopia stands as the second populous country in Sub-Saharan Africa, next to Nigeria, which has an estimated population of above 109 million. That is study show that population annual growth rate was 2.6 per cent between 2007 and 2013, and 2.8 per cent between 1984 and 1994 (Central Statistical Agency of Ethiopia, 2008). According to the projections, the total population of the country will reach 94.4 million by 2017 . The share of male and female from 2012 to 2016 has been in parity, where the female population share has increased by $0.1 \%$ in 2016. However, observing the rural and urban distribution, $80 \%$ of the Ethiopian population lives in rural areas but there is an increase of 1.6 percentage points in the number of urban population which shows an internal rural-urban migration within the country.

Although five years development plan adopted in Ethiopia From 2010 to 2015, GTP, of rapid growth Ethiopia is among the world's poorest countries with a gross national income (GNI) per capita of US\$130 (World Bank, 2006). A rapid change agricultural and private sector development, including financial sector development, is therefore high on reform agenda. The banking sector is still dominated by government participation in the sectors but this is slowly decreasing with an increases of private banks accounting for $23.5 \%$ of normal banking assets.

Microfinance is recently developed and new to Ethiopia it came to existence during 1994-95 with the government as credit services are carried by various organizations in a fragmented and inconsistent ways there was a need for government to put in place a strategy for conducting and regulating their activities. For this, the government instituted a legal and policy frame work for MFIs in 1996 through proclamation 40/1996(Gebrehiwot, 2002). As the result a number of MFIs were established and start operation in many parts of the country and within short period after establishment, achieve remarkable performance (Jemal, 2003).

It is important, however, that this borrowed loan be invested for productive purpose rather than consumption 
and generate additional income to be repaid to the lending institutions. But, increase in default rate is one of the major problems of lending institutions (Singh et al, 1985). For instance, it has been reported that loan recovery ratio in Ethiopia declined from 50\%in 1990 to 37\% in 1991 and further dropped to 15\% in 1992 (Amare, 2005). Micro Finance Institutions (MFIs) targets to the poor because these people usually lack of collateral to borrow, no steady employment and verifiable credit history, which therefore, cannot even meet the minimal standard to gain access to normal banking for collateral and other reasons.

The process of issuing loan by financial institutions goes hand-in-hand with risks such as loan repayment risk (Santomero, 1997). In order for the financial institutions to reduce risks they should adopted appropriate and effective loan repayment environment and policy (Robert, 2014). MFIs will try to reach a best level of on time repayment rate i.e. $100 \%$. If borrowers failure to repay loan the financial institutions are not able to provide loans to new applicants (Chijoria, 1997). High loan repayment rate performance is an important positive signal when MFIs have to raise new funds. Thus it benefits both the institution and the borrowers. Understanding what the MFIs should do to meet these objectives relay on factors influencing credit repayment (Robert, 2014).

Moreover the main features of the microfinance institution, which differentiate it from other commercial institutions, are they are a substitute for informal credit, generally requires no physical asset collateral, have simple procedures and less documentation, mostly group lending, easy and flexible repayment scheme, financial assistance of members of group in case of emergency, the most disadvantaged segments of population are efficiently targeted, and establish groups interaction with each other's.

In the same manner the major objectives of microfinance schemes are to stop exploitation of the poor caused by expensive informal credit, provide small loans to poor people at relatively lower cost as compared to accessible informal loans, finance economically and socially viable projects those, other financial institutions other than MFI, cannot be financed otherwise, empower women within households as decision makers and in society through active economic participation, create maximum employment opportunities, create self-sufficient and self-employed people, and reduce poverty, accelerate growth and improve the living standards on sustainable basis.

In Ethiopia, among other things, lack of finance is one of fundamental problems hindering production, productivity and income of both urban and rural households. Since access to institutional finance is limited, the majority of the poor obtain financial services through informal channels; such as money lenders, Ikub (ROSCA), relatives and others (Wolday, 2004).

Hence flexible loan with favorable terms and condition for clients as well as other borrowers would generally be preferential because better return would be assured quickly. It means if the borrowers receive the loan at the right time and condition or based on the borrower cash flow, it will simplify and assure the timely loan repayment.

The bankers concentrate only on disbursement of loans which leads to poor recovery and the schemes becomes non-viable (Rath, 1985; Rao et al., 1990). Obviously in the case of group loan the onus of repayment of external loan is not on individual borrowers but on the group as whole. This joint and several liability mechanisms (in the case of group loan) solve the three major problems which affect the loan repayment performance of the borrowers and that are common to individual lending to the poor. Those are: (i) problem of adverse selection, i.e. the risk of a borrower is clearly selected as members are self and co-selected (Besley, 1994; Yaron, 1994), (ii) problem of moral hazards, i.e. it makes sure of proper utilization of loan so that a borrower is in a position to repay loan within the due date, and (iii) problem of enforcement, i.e. pressure mechanism is operative on willful defaulters (Verhelle and Berlage, 2003).

Hence, microfinance through group loan has evolved as an accepted institutional framework to provide financial services to the poor in the absence of any security to reduce the default. Furthermore large number of microfinance institutions in Ethiopia has progressed an important of sustainability. Although the development of microfinance institutions started very recently, however, the industry showed high a growth.

It has been recognized that some of the OCSSCOs branches were weak in credit collection and making follow up on loan repayment upon the schedule, especially those in rural areas, thus resulting in loan delinquency which affect future profitability and sustainability of the institution. Hence the aim of this study is to analyze the determinants of loan repayment performance of OCSSCO's borrowers with particular reference to borrowers in Shashamane district of Oromia. It also necessitates the need for making an empirical investigation on the factors behind the default problems so that the lending units in OCSSCO could make an appropriate precaution in its lending decision.

\section{Statement of the Problem}

Majority of the world poor live in developing countries. In most of the cases they are unable to earn sufficient income to lead their live hood and hence felt under poverty. But in different ways it is possible to overcome the problems associated with poverty out of which arranging credit scheme targeting the poor is one. A number of scholars suggest their opinion that making credit available for the poor contributes to poverty alleviation. Gibons(1992) argue that the best way to do something to overcome poverty is to motivate the stockholders do something on their own because nobody have more interest to overcome the situation than the concerned body 
themselves.

It is generally known that the poor are excluded from credit facilities of the formal financial institutions such as banks for many reasons. These include insufficient collateral to support their loan, high transaction cost, unstable income, lower literacy and high monitoring cost. Micro Finance Institutions therefore is established to fill this gap by providing loans to poor and low income groups. This helps them to alleviate poverty and enhance their business activates (Mohn Noor Mohd Sharaiff, 2016.)

Loan default affects bank's cash-flow management and reduces new applicants' access to credit. It is obvious that many rural credit schemes have sustained heavy losses because of poor loan repayment. And, thus, they have been dependent on government subsidy to cover the losses they faced through loan default. MFIs should rather depend on loan repayment to be sustainable, so that they can meet their objectives.

Whether default is random and influenced by erratic behavior or whether it is influenced by certain factors in a specific situation, therefore, needs an empirical investigation so that the findings can be used by micro financing institutions to manipulate their credit programs for the better" (Khandker et al. 1995). One way to solve the loan repayment problem is to investigate the factors which affect the loan repayment of MFIs., (Onyeagochaet al,2012) although loan repayment performance is determined by willingness, ability and other characteristics of the borrowers; businesses characteristics and characteristics of the lending institutions including product designs and suitability of their products to borrowers. Regarding the characteristics of borrowers, repayment of loans depends on the willingness and ability of the borrowers to repay. Therefore, individual borrowers can either repay their loans to the institutions or choose to default their loan. It is also true that the factors influencing loan repayment capacity among borrowers not only likely to differ by programs but also differ from country to country, individual to individual, group to group depending on the domestic business and economic environment (Tundui, 2013).

Oromia credit and saving Share Company is one of the major micro financing institution of oromia regional state in Ethiopia working by provide credit and saving services to urban and rural poor who do not have access to financial services from formal banks in shashemene branch. The amount of loan oromia credit and saving Share Company provide for shashemene branch borrowers in the past few years have not fully repaid. However, to outreach large number of poor and lift themselves out from poverty, the numbers of defaulters the loan have been challenging the institution's social, economical as well as financial objectives by default large amount of loan, as a result this affect it not to solved to ward poverty reduction strategy and its realization of sustainability by diminishing loan repayment rate. This implies that oromia credit and saving Share Company of the shashemene branch is facing financial constraints to sustain loan provision to the poor due to problem of the low loan repayment performance.

Hunte as cited in Jemal, (2003) argue the default problems destroy lending capacity since as the flow of repayment decline it makes to seek government subsidy in sever case for recovery. It is clear that credit scheme targeting the poor faces heave loss due to repayment problems. Hence it is advisable to identify factors which determine loan repayment performance in Micro finance Institution (OCSSCO in this case).

Having this importance, few studies have been conducted on operation of OCSSCO in Oromia Regional State in general and the study area in particular, example study conducted by Jemal (2003). More over the previous studies focused only on rural and urban poor only. But OCSSCO is currently serving Government Employees (GE) in addition to the previous target groups which call for another study using different method from the previous work. In addition, this study was conducted priori to 2003 and now a days the economy of the country is expanding significantly and this may improve households income which enhance their loan repayment performance. On the other hand the previous work did not include some key variables that determine loan repayment performance.

In view of the above mentioned problems, the following questions can be raised and answered through the course of the study. What are the factors that can determine loan repayment?, how they influence loan repayment?, what are the benefit obtained from such institutions by the target groups? In what way the result of the study helps policy makers? etc.

In this regard, this study would be conducted to identify the determinants of loan repayment in OCSSCO borrowers of Shashamene district which have significant contribution to the literature for further studies by filling partially the gap in the area.

To the extent of my knowledge there is no study undertaken on analyzing loan repayment performance and factors affecting it in the shashemene branch. Therefore, this initiated present study to examine the factors that determine the performance of the group and individual borrowers or loan repayment of oromia credit and saving Share Company at shashemene branch in oromia region, Ethiopia.

\section{Research Methodology}

The study was conducted in the selected kebele of shashemene District on selected sample borrowers from 2018/19 to 2019. It's located in west Arsi Zone of the Oromia National Regional State, approximately $250 \mathrm{~km}$ south of Addis Ababa. Geographically, the town is located at 7-degree North Latitude and 38-degree East Longitude. The town is economically important and expanding quite rapidly compared to other towns. This is 
perhaps due to its location as a crossroad and a junction point for most towns located in the southern part of the country. It serves as an international highway route connecting Ethiopia with Kenya. The town also lies within the Ethiopian Rift Valley and is close to the lakes and holiday resorts of Hawassa, Langano and Shalla-Abiyata Park.

The urban land of Shashamane stretches over 1,858 hectares of land. Climatically, Shashemene district falls into three climatic zones known as Dega, Woinadega and Kolla. Its altitude ranges from 1,672 to 2,722 meters above sea level. The temperature level ranges from $12-28^{\circ} \mathrm{C}$ and yearly rainfall varies from $1,500-2,000 \mathrm{~mm}$. There are four rivers (Laftu, Melka, Oda and Essa) that flow through the town towards Lake Shala. Dhedhaba is another major river that serves as a natural boundary between Shashemene and ArsiNegele. According to the official Central Statistical Survey, the total population of Shashemene was estimated to reach over 73,560 in 2001 which is currently more than total 73,560 populations in 2018 . The Shashemene town has been restructured into ten administrative units called sub city which are managed by the Municipality. Namely: 1--awasho, 2- allelu- 3 bulchana -4-arada-5-abosto - 6- didaboke and -7- Burka gudin.

The study employed explanatory and descriptive research design with quantitative and qualitative methods. The primary data has been collected from OCSSCO's borrowers and credit committee members. Some important secondary data used in this study was also taken from OCSSCO's official records. The loan disbursed for ten rounds (from 2008 to 2017/18) was considered by the researcher and finally the data of the loan disbursed in the year 2017/18 was taken since it yields the current information. The survey was collected using structured questioners to be administered using trained enumerators. Four enumerators who complete grade 10 and know culture and social values of the respondents and the local language were employed to carry out the survey. At first they were given appropriate training and well oriented about the objectives of the study, the content of the questioner and how to approach the respondents to collect the required information. Pre- testing of the questioner was carried out on five respondents and depending on the result some adjustment was made to the final version of the questioner. The survey questioner was adapted from some related studies like Jemal, 2003; Amare, 2005 and Fitsum, 2014 and revised as it fits the current study. The study also uses interview during collection of data from OCCSSCO's credit committee and document review to obtain secondary data used by the branch office.

In the study area, both the town and the PAs in the rural are embraced by OCSSCO's credit scheme. A multistage sampling technique was employed to get the required primary data. At the first stage the three kebeles of the urban and 8 PAs from the rural were purposively selected to generate the necessary data. In the second stage, stratified sampling and simple random sampling was adopted to select the respondents for the study. The total population was divided in to 3 stratum based on the nature of the borrowers. Strata one consists of rural borrowers, strata two urban borrowers and strata three GEs. Accordingly, from two kebele 169 households were selected through proportional random sampling techniques. The sample for the study was drawn from the three stratums following the method of proportional allocation in which the size of the sample from the stratum relatively kept proportional to the size of the strata. Cochran's (1977) sample size determination formula was adopted to get sample respondents in estimating the mean or proportion of the finite population.

$$
\text { no }=\frac{z^{2}(p)(q)}{d^{2}}
$$

Where: $\mathrm{n}_{\mathrm{o}}=$ sample size, $\mathrm{Z}=$ value of selected alpha level of 0.025 in each tail (for $95 \%$ degree of Confidence) $=1.96,(p)(q)=$ estimate of variance $=0.25, d=$ accepted margin of error for proportion being estimated $(5 \%)=$ 0.05

But this is not the final sample size; to obtain the final sample size the total target population should be considered. Hence, Cochran's correction formula was used to obtain the final sample size of the survey.

$$
\mathrm{n}=\frac{n_{O}}{1+\frac{n_{O}}{N}}
$$

$\mathrm{n}=$ final sample size of the survey

$\mathrm{N}=$ total population of the study

This sample was selected from each stratum using relative proportionate allocation in relation to the total population. The number of respondents from each stratum was determined using the following formula:

$$
\begin{aligned}
& \mathrm{n}_{\mathrm{i}}=\left(\frac{N_{x}}{N_{y}}\right) \cdot \mathrm{n} \\
& \mathrm{ni}=\text { sample size from each stratum } \\
& \mathrm{Nx}=\text { total population in each stratum } \\
& \mathrm{Ny}=\text { total population of the study and } \\
& \mathrm{n}=\text { total sample size of the study (Cochran, 1997) }
\end{aligned}
$$


Table 3.1 proportionate sample size from each stratum

\begin{tabular}{|l|c|c|}
\hline Nature of respondent & Total number of borrower & proportionate sample size \\
\hline Rural borrowers & 2150 & 136 \\
\hline Urban borrowers & 398 & 25 \\
\hline GEs & 210 & 8 \\
\hline Total & 2758 & 169 \\
\hline
\end{tabular}

Source: Shashamane Town OCSSCO Office, (2018).

In order to identify the determinants of loan repayment performance probit regression model would be employed. Loan repayment performance is not as such continuous variable and cannot be analyzed using linear regression model like continuous variables. When the dependent variable in a regression model is binary in nature the analysis can be conducted using linear probability, logit or probit model. Here loan repayment equation can be specified on the basis of the assumption that the decision of a given borrower either to pay loan in full or not is probabilistic and depend on some unobservable variable (utility index) $U_{i}$ which can be explained by a set of variables.

This utility index which indicate the probability of repaying loan in full or not can be represented by the equation:

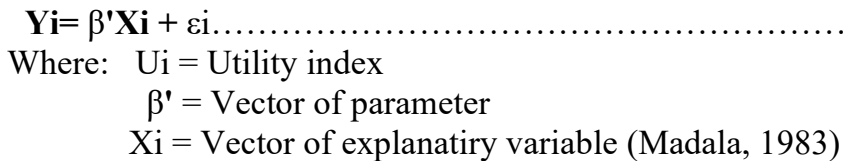

The utility index is used to analyze loan repayment performance because a given borrower repay loan if there exist some benefit from retailning. The Ui indicates the prabability of repaying loan in full and will be greater if its value is larger. (Mengistu, 1997).

The value of loan repayment (LRP) lies between 0 and 1 and fit well to the non-linear relation between the variables (Gujarati, 2003). For this reason, it is best to use logit or probit model for analysis.

To relate Ui with LRPi let the following assumption holds;

$\mathbf{L R P i}=\mathbf{1}$, if $\mathbf{U i}>\mathbf{0} \ldots \ldots \ldots$...... (borrower pay loan in full) and

$\mathbf{L R P i}=\mathbf{0}$, if $\mathbf{U i}<\mathbf{0} \ldots \ldots \ldots \ldots$ (borrower did not repay loan in full)

Where LRPi is loan repyment for $\mathrm{i}^{\text {th }}$ borrower.

Assuming Ui to be normally distributed with zero mean and variance $\delta 2$, the probability that Ui $>0$ can be computed as ;

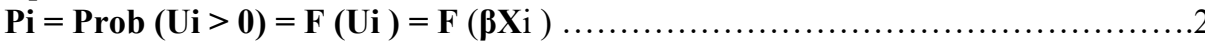

Where $\mathrm{F}=\mathrm{CDF}=$ Cummulative Distribution Funcation

Hence the joint probability is given by: (Madala, 1983)

$\mathbf{L}=$ ЛLRi=1 Pi Л $\mathbf{L R i}=\mathbf{0}(\mathbf{1 - P i})$

The probability of loan repayment in full is non-linearly related to a set of explanatory variables giving rise to the estimated probability be lay in the interval 0 to 1 . This type of expectation gives us CDF from which the logistic and the normal CDF generated. The CDF give rise to logit and probit model respectively (Gujarati, 2003; Rubinfeld, 1981). Thus the model for loan repayment can be represented by:

$L R P=f(A G E, S E X, E D U C, S R P, I N C, I N C A, F S, N D, L S, L V S T, S P V, L D R, T M, R A, L M, G P, \Phi)$

Where, $\Phi=$ Random variable

$L R P=$ probit $p=\alpha+\beta_{1 a g e}+\beta_{2 s e x}+\beta_{3} e d u c+\beta_{4 s} r p+\beta_{5 i n c}+\beta_{6}$ inca $+\beta_{7} F s+\beta_{8} N d+\beta_{9} L s+\beta_{10 l v s t}+$

$B_{11 s p v}+\beta_{12} l d r+\beta_{13 t m}=\beta_{14} R a+\beta_{15} L m+\beta_{16} G p+\Phi$. 
Table 1: Description of Model Variables

\begin{tabular}{|l|l|l|}
\hline & Types of variable & Expected sign \\
\hline Age of the borrower( Age) & Continuous variable & + \\
\hline Sex of the borrower(Sex). & Dummy variable & $+/-$ \\
\hline Educational level of the borrower (Educ) & Continuous variable & + \\
\hline Loan size in Birr (Ls) & Continuous variable & + \\
\hline Timeliness of loan release (TM) & Continuous variable & - \\
\hline Loan Diversion (LDR) & Continuous variable & + \\
\hline Income from activities financed by loan(INC) & Dummy variable & + \\
\hline Annual income from other activities(INCA) & Continuous variable & + \\
\hline Number of livestock (LSTK ) & + \\
\hline suitability of repayment period(SRP) & Continuous & $+/-$ \\
\hline Adequacy of supervision visits made to a borrower(SPV) & Dummy & + \\
\hline Family size of borrower(FS) & Continuous & - \\
\hline Number of dependents in the family (ND). & Continuous Variable & \\
\hline Borrowers Residential Area (RA). & & - \\
\hline Grace period (GRP). & Continuous & - \\
\hline Lending Methodology (LM). & Dummy & - \\
\hline
\end{tabular}

\section{Result and Discussion}

The results of analysis have been conducted to address the main and specific objectives of the study. This part was divided in to four major sections. The first section of this part presents demographic characteristics of sampled respondents such as, gender, age, marital status, educational level and sectors which they can lend. In the second section, the statistical descriptions of the factors that influence the loan repayment performance of OCSSCO in the study area were discussed. In the third section, the econometric specification of the model and their respective tests were conducted. In the fourth section, the econometric results and the interpretations of the independent variables having three sub categories like, lenders related factors; lenders related factors and external related factors that were identified as the most important determinants of loan repayment performances were explained in detail.

\subsection{Descriptive Analysis}

This part firstly, presents demographic characteristics of sampled respondents such as, gender, age, marital status, educational level and borrowers they can lead. Secondly, the statistical descriptions of the factors that influence the loan repayment performance of borrowers based on the descriptive analysis were discussed.

Descriptive statistics analysis made use of tools such as mean, percentage, standard deviation and frequency distribution. Beside $t$ and Chi-square test statistics were employed to compare defaulter and non- defaulter group with respect to explanatory variables.

As it was indicated in the preceding chapter, OCSSCO disbursed loan for 2758 borrowers in the year 2017/18. From these total populations 169 respondents were randomly selected and included in the survey.

Table 4-1 Description of demographic \& Socio-economic characteristics of Respondents

\begin{tabular}{|l|l|l|l|l|l|l|}
\hline variables & Obn. & Mean & SD & Min & Max & t-value \\
\hline AGE & 169 & 37.053 & 7.877 & 20 & 56 & -3.3546 \\
\hline SEX & 169 & .8047337 & .0305834 & 0 & 1 & 4.02 \\
\hline EDUC & 169 & 3.183 & 4.377 & 0 & 16 & 0.1402 \\
\hline INC & 169 & 2286.065 & 1003.097 & 0 & 4500 & -4.4521 \\
\hline INCA & 169 & 2037.219 & 1974.437 & 0 & 19000 & -3.0688 \\
\hline FS & 169 & 4.112 & 2.008 & 0 & 14 & -0.7025 \\
\hline ND & 169 & 2.7 & 1.69 & 0 & 8 & 1.4391 \\
\hline LS & 169 & 4207.101 & 1802.367 & 1000 & 15000 & -.8168 \\
\hline LVST & 169 & 2.16 & 1.08 & 0 & 5 & -2.8697 \\
\hline
\end{tabular}

Source: Computed from own survey Data (2019)

According to table 4.1 above, the number of observation is 169 . The minimum and maximum age of the respondents are 20 and 56 respectively with average age of the whole sample 37.053 years. Borrowers' level of education was averaged at 3.183 with 0 and 16 being minimum and maximum respectively. This confirmed that most of the respondents are illiterate The maximum income gained from activities financed by the loan is 4500 birr and the maximum income gained by respondent from other source is birr 19000 birr.

The loan size disbursed to the borrower ranges between 1000 and 15000 birr. The maximum family size and 
number of dependents are 10 and 14 while the minimum is 1 and 0 respectively. The average number of livestock owned by the respondents is 2 which are too small to support the loan repayment.

Table 4.2 Composition of Respondents by age group and Residential Area

\begin{tabular}{|l|c|c|}
\hline \multirow{2}{*}{ Age group } & \multicolumn{2}{|c|}{ Residential Area } \\
\cline { 2 - 3 } & Urban & Rural \\
\hline $22-36$ & 23 & 45 \\
\hline $37-49$ & 17 & 63 \\
\hline $50-65$ & 0 & 21 \\
\hline
\end{tabular}

Source: Survey Data (2019)

The mean age of the rural borrowers is 42.5 while that of urban is 35 . This shows that urban borrowers are on average younger than rural borrowers. $23(57.5 \%)$ of the urban borrowers and $45(34.89 \%)$ of the rural borrowers belongs to the age group 22-36, $17(42.5 \%)$ of the urban borrowers and $63(48.84 \%)$ of the rural borrowers belongs to the age group 37- 49 and no borrowers form the urban belongs to the age group 50-65 while $21(16.28 \%)$ of the rural borrowers belongs to this age range.

Table 4.3 Respondents Residential Area and Education Level

\begin{tabular}{|c|c|c|c|c|c|}
\hline \multirow{2}{*}{$\begin{array}{l}\text { Residential } \\
\text { Area }\end{array}$} & \multicolumn{5}{|c|}{ Borrowers Education Level } \\
\hline & 0 & $1-8$ & $9-12$ & $>12$ & Total \\
\hline Urban & 6 & 8 & 17 & 14 & 45 \\
\hline Rural & 76 & 30 & 12 & 6 & 124 \\
\hline Total & 82 & 38 & 29 & 20 & 169 \\
\hline
\end{tabular}

Source: Survey Data (2019)

Table 4.3 revealed most of the respondents in the sample, $82(48.5 \%)$ are illiterate. $38(22.5 \%)$ respondents attended elementary schooling system, 29 (17.16\%) respondents attended high school education and $14(8.28 \%)$ respondents from urban go beyond grade 12 . Generally, respondents from urban are more educated as compared to borrowers from rural due to access to education facilities. This shows that more educated borrowers more likely repay their loan timely than those less educated borrowers. In other expression the borrowers those attained lower education levels were more defaulter than those attained higher education level.

Table 4.4 Respondents Reason for Default

\begin{tabular}{|l|c|c|}
\hline \multicolumn{1}{|c|}{ Reason } & frequency & Percent \\
\hline Loan Diversion & 3 & 6,53 \\
\hline Disaster & 12 & 26.09 \\
\hline $\begin{array}{l}\text { Activities financed by } \\
\text { The loan not profitable }\end{array}$ & 25 & 54.34 \\
\hline Personal problem & 4 & 8.70 \\
\hline $\begin{array}{l}\text { Different celebrations } \\
\text { (Wedding etc.) }\end{array}$ & 2 & 4.34 \\
\hline
\end{tabular}

Source: Owen Survey Data (2019)

Table 4.4 reviled the main reason for the default. From the survey response $3(6.53 \%)$ respondents default due to loan diversion, $12(26.09 \%)$ natural disaster, $25(54.34 \%)$ due to non- profitability of activities financed by the loan, $4(8.70 \%)$ due to personal problems like sick and $2(4.34 \%)$ due to ceremonial celebrations like wedding, teskar, mahiber etc.

Table 4.5 Respondents by Area and Purpose of Borrowing

\begin{tabular}{|l|c|c|c|}
\hline \multicolumn{1}{|c|}{ Purpose of Borrowing } & \multicolumn{2}{c|}{ Residential } & Area \\
\cline { 2 - 3 } & Urban & Rural & \\
\hline Purchase of agricultural inputs & 0 & 64 & 64 \\
\hline Purchase of farm oxen & 0 & 35 & 35 \\
\hline Petty trade & 24 & 0 & 24 \\
\hline Animal Fattening & 0 & 8 & 8 \\
\hline Fattening and petty trade & 13 & 5 & 18 \\
\hline Education fee & 3 & 1 & 4 \\
\hline House construction & 6 & 0 & 6 \\
\hline Other & 0 & 10 & 10 \\
\hline Total & 46 & 123 & 169 \\
\hline
\end{tabular}

Source: survey data (2019)

The need to construct this table is to relate the purpose of borrowing and loan repayment performance by accessing weather the borrowers use the loan for intended purpose or not. Accordingly, 24 (52.17) of urban borrowers need the loan to conduct petty trading and $35(28.455 \%)$ of the rural borrowers need the loan to purchase farm oxen, $64(52.032 \%)$ for purchase of agricultural inputs like fertilizer and improved seeds, 13(28.26\%) of 
urban borrowers for petty trade and the rest for specified purposes in the above table.

\section{Defaulters VS Non-Defaulters}

Under this section the researcher attempts to compare credit worthy borrowers and non- credit worthy borrowers. This is done by identifying the determinants of loan repayment with respect to the two categories.

Table 4.6 Summary statistics \& t-test of significant continuous variables

\begin{tabular}{|c|c|c|c|c|c|c|}
\hline \multirow{3}{*}{ Variables } & \multicolumn{4}{|c|}{ Loan Repayment Performance Status } & \multirow{3}{*}{$\begin{array}{l}\text { Mean } \\
\text { Difference }\end{array}$} & \multirow{3}{*}{ T-Test } \\
\hline & \multicolumn{2}{|c|}{ Non- Defaulters } & \multicolumn{2}{|l|}{ Defaulters } & & \\
\hline & Mean & SD & Mean & $\mathrm{SD}$ & & \\
\hline Inc & 2485.285 & 927.663 & 1753.37 & 1021.379 & -771.915 & $-4.4522 *$ \\
\hline Age & 38.26 & 7.497 & 33.82 & 8.042 & -4.434 & -0.3546 \\
\hline Fs & 3.93 & 1.844886 & 4.17 & 2.679673 & 0.93 & $2.2241 * *$ \\
\hline Ls & 4276.423 & 1976.505 & 4021.739 & 1220.002 & -254.6836 & -0.8168 \\
\hline Educ & 3.15 & 4.422 & 3.26 & 4.3021 & -.1063 & $2.4586 * *$ \\
\hline
\end{tabular}

NB. $*=1 \%, * *=5 \% \quad$ Source: Survey Data (2019)

As it can be seen from table 4.7 above, defaulters and non-defaulters differ substantially with respect to the specified variables. Out of 8 continuous variable included in the equation the two group differ significantly (at $1 \& 5 \%$ level) in 5 of them. On the other hand out of 8 discrete variables used in the model defaulters and nondefaulters are different significantly (at $1 \%, 5 \% \& 10 \%$ ) in 5 of them. Accordingly, the t-test and chi-square test were used to compare defaulters and non-defaulters and the values confirmed the difference between the two groups is significant.

In addition, as it was clearly described in the preceding sections, there was significant number of defaulters in the sampled respondents. $123(72.78 \%)$ of the surveyed sample borrowers have repaid their loan fully while 46 $(27.22 \%)$ have been defaulted.

The mean age for defaulters is 33.82 years while the mean age for non-defaulters is 38.26 . This shows the mean age of non-defaulters is slightly higher than the mean age of defaulters. This indicates that as age increases LRP decreases and age is negatively related to LRP.

Regarding loan size, the mean loan size of non-defaulters is birr 4021.739 and that of defaulters is 4276.423 This shows as the loan size increases LRP decreases and there is a negative relationship between high loan size and loan repayment performance.

\subsection{Econometric Analysis}

Here under, model estimation was presented in and the outcome of model estimation using econometric regression was discussed in detail. The goodness of fit-model checked at first using Hosmer-Lemeshow model test. Table 4.7 Probit model for lrp, goodness-of-fit test

\begin{tabular}{|c|c|c|}
\hline Chi-square & Df & Sign. \\
\hline 4.43 & 8 & 0.82 \\
\hline
\end{tabular}

As it can be observed from the table above the significance level is 0.82 (greater than $5 \%$ ) indicating the model used to carry out economic regression is best.

Then the hypothesized explanatory variables were checked for the existence of multicollinearity, a serious problem in cross sectional data. It is a problem raised if at least one of the independent variables is a linear combination of the others. The existence of multicollinearity can cause the estimated regression coefficient to have wrong sign and small t-ratio leading to wrong conclusion.

The presence of such problem can be checked by using the two commonly known tests, VIF (variance Inflation Factor) and Contingency Coefficient. VIF is used to check correlation among continuous variables while contingency coefficient is used to check associations among discrete variables. The value of variance inflation factor can be obtained as:

$$
\mathrm{VIF}=1 / 1-\mathrm{Ri}^{2}
$$

Where, $\mathrm{Ri}^{2}$ is the square of multiple correlation coefficients that results when one explanatory variable say, $x i$ is regressed against all other explanatory variables.

If the value of VIF is greater than 10, this indicates that there is a problem of multicollinearity. The VIF value displayed below shows there is no serious problem of multicollinearity (see appendix)

In similar fashion, contingency coefficient was computed to check the presence of multicollinearity problem among dummy explanatory variables and can be computed as:

$$
\mathrm{C}=\sqrt{\frac{{ }^{2}}{N+{ }^{2}}}
$$

Where, $\mathrm{C}=$ coefficient of contingency,,$=$ Chi-square of random variable $\& \mathrm{~N}=$ total sample size.

The decision rule for contingency coefficient is that when its value is above 0.8 (approaches 1 ) there is a 
severe problem of association between dummy explanatory variables. If its value is less than 0.8 , this indicates that there is no severe problem of association among the discrete variables.(see appendix)

4.2.3.1. Interpretations of the coefficients in the model

In this model we are not allowed to interpret the magnitude of the independent variables rather only the sign of the variables across the model was interpreted based on the classifications of the independent variables related factors such as; the lenders or MFI, enterprise and the external related factors that influence the loan repayment performance of borrowers financed by OCSSCO branches focusing on the significant variables ("P $>\mathrm{z}$ " $<0.1$ ) in the model. A total of 16 explanatory variables were considered in the econometric model. Out of which 9 variables were found to be significant.

Table4, 8 Probit Estimate

\begin{tabular}{|c|c|c|c|c|c|}
\hline Lrp & Coef. & Std. Err. & Z & $\mathrm{P}>\mathrm{Z}$ & Marginal effect \\
\hline Age & .0443947 & .0193188 & 2.30 & 0.122 & .012137 \\
\hline sex & .4331765 & .3692493 & 1.17 & 0.041 & .131205 \\
\hline educ & -.0915642 & .0436726 & -2.10 & 0.036 & -.0250326 \\
\hline Srp & 1.149618 & .3926288 & 2.93 & 0.003 & .3945632 \\
\hline Inc & .0005448 & .000173 & 3.15 & 0.002 & .0001489 \\
\hline inca & .0001442 & .0001018 & 1.42 & 0.157 & .0000394 \\
\hline Fs & .1618572 & .0843183 & 1.92 & 0.055 & .0442499 \\
\hline $\mathrm{Nd}$ & -.1673989 & .1181509 & -1.42 & 0.157 & -.0457649 \\
\hline Ls & .0002199 & .0001183 & 1.86 & 0.063 & .0000601 \\
\hline lvst & .0404161 & .1399012 & 0.29 & 0.773 & .0110493 \\
\hline spv & -.4163515 & .4744468 & -0.88 & 0.380 & -.097932 \\
\hline $\mathrm{Ldr}$ & 1.177427 & .4198197 & 2.80 & 0.005 & .4002184 \\
\hline $\mathrm{Tm}$ & -.2769094 & .333145 & -0.83 & 0.406 & -.0706221 \\
\hline $\mathrm{Ra}$ & -.7910179 & .3323139 & -2.38 & 0.017 & -.2499307 \\
\hline $\mathrm{Lm}$ & -1.122718 & .7200574 & -1.56 & 0.119 & -.1854337 \\
\hline $\mathrm{Gp}$ & -3746929 & .3868334 & -.97 & 0.033 & -.0905452 \\
\hline Cons & -3.427564 & 1.511042 & -227 & 0.023 & \\
\hline
\end{tabular}

Number of Obs $=169$, LR Chi $^{2}(16)=97.92$, Prob $>\mathrm{Chi}^{2}=0.0000$, Pseudo $\mathrm{R}^{2}=0.6571$, Log likelihood=-25.557326

According to table 4.8, nine of the sixteen explanatory variables included in the estimation of the econometric model of loan repayment performance were found to be significantly influence the probability of being nondefaulter or defaulter of the borrowers. These are s Sex of the borrower(Sex), education level of the borrower (educ.), income from activities financed by the loan (inc), loan size(ls), family size of the household (fs), loan diversion rate (ldr), residential area of the borrower (ra), suitability of repayment period (srp ) grace period (gp). The remaining other; Income cumulated by loan (inca), , number of dependents in the household (nd), Sex of the respondent, number of livestock owned (lvst), timeliness of loan release (tm), and adequacy of supervision (spv), were found to have no significant effect on loan repayment performance but related either positively or negatively to it.

Sex of the respondent was significant at $5 \%$ and positively related to loan LRP. At first, it was difficult to decide the sign of this variable because, some researcher believe that females are better payers than male borrowers (Vigano, 1999) while others found the opposite result. This study yield male borrowers are better in repaying their loan as compared to females. The positive sign shows male borrowers performed better in loan repayment.

Education level of the borrower is important borrower's factor that affected LRP negatively at 5\% significance level. The variable was expected to have positive sign but the result of the study (table 4.8) proved the variable to have negative sign in the equation of the model and is inconsistent with the first estimate. The higher years of group borrower's education level by $1 \%$ increases or decreases the more likely to be repaying the loan by less educated borrowers. So as the education level increases the probability of repaying the loan increases $2.5 \%$ and the probability of not repaying the loan decreases. This is agreed with the expectation and with the find in $g$ result of Shu-Teng et al (2015); Nancy and Mohamed (2014); Ann mukono (2015); Benjamin et al (2017); Yilkal (2015); Tolosa (2014); Mesele et al, (2016); Tenishu (2014) and Ababiya et al (2015)..

Income from activities financed by the loan is one of the factors which affected LRP of the borrowers and significant at $1 \%$ level. An increment in income of household from activities financed by the loan increases the probability of being non-defaulters. This enhances a borrower capacity to repay loan. It was difficult to determine the sign of the variable prior, but now the study result showed that this variable affected LRP positively.

Family size is also one of the factors that affected LRP of the borrowers negatively with significance level of $5 \%$. It was expected that the variable will have negative sign taking the case of large family size. Hence, the estimated result of the model coincided with the expected sign. This shows that larger family size increases the probability of default by $4.4 \%$ of marginal effect coefficient high consumption expenditure which results in low 
income to be left over to repay the loan.

Loan diversion is another borrower's factor which affected LRP positively and is significant at $1 \%$ level. It was expected that this variable has negative sign if the loan is diverted to less productive activity than the intended one and positive sign if it is diverted to more productive activity. From the model estimate, loan diversion has positive sign indicating loan is diverted to more productive purposes.

Residential area is another important factor that affected LRP negatively being significant at 5\% significance level. This variable was expected to have negative sign and impact on LRP. The result from the estimate coincide the expectation so that residential area of the borrower affected LRP negatively.

Loan supervision or follow up was found that positively and statistically significantly influence loan repayment performance at $10 \%$ significance level. Holding other variables constant an increase is a one-time in the frequency follow up activities by the loan officer of OCSSCO in the business leads to increase the probability of business repaying the loan by $0.40 \%$ in the study area. The result is in line with the prior expectation and with the result of Firafis (2015); Tenishu (2014) and Tesfatsion et al (2015).

Finally grace period is the variable that affects LRP negatively and significantly at $5 \%$ level of significance. This indicates that the shorter the grace period the more the borrowers become defaulters. The estimated result coincides with the expected sign.

\subsection{Conclusion and Recommendation}

On the basis of the analysis and description of demographic and socioeconomic characteristics of borrowers, loan related factors and institution factors that determine LRP the following conclusion and recommendations can be made.

The result of the study has shown that out of total respondents, only 33(19.5\%) are women and this shows men clients benefited more than women, which contradicts the policy objectives of OCSSCO. The institution should improve women participation both in rural and urban areas since the current data is inconsistent with OCSSCO's objectives in particular and that of the country in general.

From the survey result, out of 169 respondents included in the study, 46 (27.22\%) become defaulted while $123(72.78 \%)$ repaid their loan. So borrowers have to repay the loan on time so that the institution become sustainable and deliver the next loan. To this end the institution should take great care during screening not to exclude credit worthy borrowers and include non -credit worthy borrowers. The government also should stand along the institution in case of default and enforce the defaulters to repay the loan.

Sex of the respondent was significant at $5 \%$ and positively related to loan LRP. At first, it was difficult to decide the sign of this variable because, some researcher believe that females are better payers than male borrowers (Vigano, 1999) while others found the opposite result. This study yield male borrowers are better in repaying their loan as compared to females. The positive sign shows male borrowers performed better in loan repayment.

Education level of the borrower is important borrower's factor that affected LRP negatively at 5\% significance level. The variable was expected to have positive sign but the result of the study (table 4.8) proved the variable to have negative sign in the equation of the model and is inconsistent with the first estimate. The higher years of group borrower's education level is the more likely to be repaying the loan than less educated borrowers. So as the education level increases the probability of repaying the loan increases and the probability of not repaying the loan decreases. So that the government and non-government should expand educational in the study area

Income from activities financed by the loan is one of the factors which affected LRP of the borrowers and significant at $1 \%$ level. An increment in income of household from activities financed by the loan increases the probability of being non-defaulters. This enhances a borrower capacity to repay loan. The study result showed that this variable affected LRP positively. So as the borrower earn more and more income they built a potential to repay their loan easily.

Family size is also one of the factors that affected LRP of the borrowers negatively with significance level of $5 \%$. It was expected that the variable will have negative sign taking the case of large family size. Hence, the estimated result of the model coincided with the expected sign. This shows that larger family size needs high consumption expenditure which results in low income to be left over to repay the loan. So government and concerned body should aware the house holds to reduce fertility and use of family planning in the study area.

Loan diversion is another borrower's factor which affected LRP positively and is significant at $1 \%$ level. It was expected that this variable has negative sign if the loan is diverted to less productive activity than the intended one and positive sign if it is diverted to more productive activity. From the model estimate, loan diversion has positive sign indicating loan is diverted to more productive purposes. Moreover, the loan diverted to more productive activities than the intended one helps to bring additional income and capacitated the borrowers to repay his/her loan.

Residential area is another important factor that affected LRP negatively being significant at 5\% significance level. This variable was expected to have negative sign and impact on LRP. The result from the estimate coincide 
the expectation so that residential area of the borrower affected LRP negatively. Urban borrowers are on average performed better in LRP than rural area so the institution should borrow for urban resident.

Loan supervision or follow up was found that positively and statistically significantly influence loan repayment performance at 10\% significance level. Holding other variables constant an increase is a one-time in the frequency follow up activities by the loan officer of OCSSCO in the business leads to increase the probability of business repaying the loan by $0.41 \%$ in the study area. So the institution should be strength supervision follow up the borrower.

As it was seen during the survey, a type of interdependence was observed between OCSSCO's credit scheme and local money lenders operating in the study area. Hence further study will be needed if this services as a source of credit for poor groups and fill the gap of limited access of financial services. If study will be carried on similar issue should stress on grace period, loan diversion to determine their impact on LRP and evaluate the consistency of my result.

\section{References}

Abafita,J. (2003) 'Microfinance and loan repayment performance: A Case Study of the Oromia Credit and Savings Share Company (OCSSCO) in Kuyu', MSc thesis, Addis Ababa

Abreham Gebeyehu (2002), "Loan repayment and its Determinants in Small-Scale Enterprises Financing in Ethiopia: Case of private borrowers Around Zeway Area”, M. Sc. Thesis, AAU.

A.H.Roslan and MohdZainiAbdKarim (2009).Department of Economics, Collage of Arts and Sciences University Utara, Malaysia,.

Amare Berhanu, 2005. Determinants of Formal source of credit loan repayment Performance of Smallholder Farmers: The Case of North Western Ethiopia, North Gondar: M.Sc. Thesis, Haramaya University, Ethiopia.

Bayeh A.K. (2012). "Financial Sustainability of Microfinance Institutions (MFIs) in Ethiopia. "European Journal of Business and Management Vol 4, No.15.

BekeleHundie, Belay Kassa and MulatDemeke, 2005.Factors Influencing Repayment of 74 Agricultural Input Loan in Ethiopia. Journal of Agricultural Economics, 1:117-120.

Belay Kebede, 1998. Agricultural Credit and Factors Impeding Loan Repayment Performance of small-holders in Central Highlands of Ethiopia: The Case of AlemgenaWoreda. M.Sc. Thesis, Haramaya University, Ethiopia.

Berhanu A. (2005) 'Determinants of formal source of credit loan repayment performance.

Besley, T.J. (1994).How do market failures justify interventions in rural credit markets. World Bank Research Observer, 9(1): 27-47.

Besley T. and. Coate, S. (1995) . "Group Lending, Repayment Incentives, and Social Collateral.” Journal of Development Economics 46, no. 1: 1-18.

Bhatt, Nitin, and Shui-Yan Tang, 2002,.Determinants of repayment in microcredit: Evidence from programs in the United States, International Journal of Urban and Regional Research 26, 360-376.

.Development Bank of Ethiopia ( 2009 ).News Letter no 1 Development Bank of Ethiopia North Region (2009) ,Annual Report.

FasikaDamtie and Daniel Ayalew, Financing Micro and Small Scale Enterprises: An Empirical Survey in Urban Ethiopia, Ethiopian Journal of Economics, Vol. VI, No.1, 1997, pp.37-52.

Fikirte K.R (2011). "Determinants of loan repayment performance: A case study in the Addis Credit and Saving Institution." Addis Ababa, Ethiopia.

Gujirati D. (1995).Basic Econometrics, 2nd edition.New York McGraw Hill international edition, economics series. Johnson, J and Dinardo (1997) p .422 commis J.B (1988) p. 53.

GebereheywotAgeba and WoldayAmha, (2004).Micro and Small Enterprises Development in Ethiopia: Survey Report, EDRI.

Ghatak, M. and Guinnane, T.W. (1999). The economics of lending with joint liability: Theory and practices. Journal of Development Economics, 60(1):195-28. Gibbouns, D.S. (1992), The Grameen Reader, 2nd edition, Grameen Bank, Dhaka.

Gobezie, Getaneh, Regulating Microfinance in Ethiopia: Making it more Effective, AMHARA CREDIT AND SAVINGS INSTITUTION (ACSI) Essay No. 3, April 2005.

Godquin, M., 2004.Microfinance Repayment Performance in Bangladesh: How to Improve the Allocation of Loans by MFIs. World Development, 32(11):1909-1926.

Hunte C. K., 1996. Controlling Loan Default and Improving the Lending Technology in Credit Institutions. Saving and Development, Quarterly Review, 1: 45-59.

JemalAbafita (2003).Micro finance and loan repayment performance, case study of the Oromia Credit and Savings Share Company (OCSSCO) in Kuyu.

Kuhn ME \&Darroch Mag (1999).Factors affecting rural medium-term loan repayment: Evidence from a South African development finance institution. In: Peters $G \&$ Von Braun J (eds), Food security, diversification and 
resource management: Refocusing the role of agriculture? International Association of Agricultural Economists (IAAE).Occasional Paper No.8.Ashgate Publishing Co. Ltd, Aldershot, UK, 1998, pp 322-328.

Long J. Scott (1997).,Regression Models for Categorical and Limited Dependent Variable. Lyne MC \&Ortmann GF (1992).Evaluation of the KwaZulu Farmer Support Programme.Second Interim Report.Unpublished report, Evaluation Programme, Centre for Policy Analysis, Development Bank of Southern Africa, Halfway House.

Mohammad Reza Kohansan and HoomanMansoori (2009) .University of Hamburg.Okorie A (2004).Major determinants of agricultural smallholder loan repayment in a developing economy: Empirical evidence from Ondo State, Nigeria. Savings and Development 1:89-98.

Martina W.et al., (July, 2008) .Sector assessment study on: Access to finance Volume 2 Steel for the German Technical Cooperation within the Engineering Capacity Building Project in Ethiopia.

MengistuBediye (1997),."Determinants of Micro enterprises loan Repayment and Efficacy of screening mechanism in Urban Ethiopia: The case of Bahir Dar and Awassa Towns', M.Sc. Thesis, Department of Economics, A.A.U.

Njoku. J. E and Obasi. P.C., 1991.Loan Repayment and its Determinants under The Agricultural Credit Guarantee Scheme in Imo State, Nigeria. Federal University of Technology, Nigeria. No. 50 (June) (Washington: World Bank).

Nawai, N. and Shariff, M. N. M. (2013) ."Loan Repayment Problems in Microfinance Programs that use Individual Lending Approach: A Qualitative Analysis.” Journal of Transformative Entrepreneurship Vol. 1, Issue 2, pp.93-99.

Olagunju FI, Adeyemo R (2007). Determinants of repayment Decision among Small Holder Farmers in Southwestern Nigeria. Pakistan J. Soc. Sci., 4(5): 677-686.

Otero, M.1999. Bringing Development Back into Microfinance, New Development Finance, held at the Goethe University in Frankfurt, September 1999. Oyatoya E.T.O., "An Economic Appraisal of Small Farmers Credit Schemes: A Cost Study of Western Nigeria ", Savings and Development, vol. VII, No.3, 1983, pp. $279-91$.

Schreiner, M. and Colombet, H.H. (2001),.From Urban to Rural: Lessons for Microfinance Schreiner, M.; and H.H. Colombet. (2001) "From Urban to Rural: Lessons for Microfinance from Argentina", Development Policy Review, Vol. 19, No. 3, pp. 339-354. Versión en español: "Las Microfinanzas en la Zona Rural de Argentina".

Stevenson L, St Onge A (2005). Support for Growth-oriented Women Entrepreneurs in Ethiopia (ILO) .

Sileshi M., Nyikal R. and Wangia S. (2012). "Factors Affecting Loan Repayment Performance of Smallholder Farmers in East Hararghe, Ethiopia.” Developing Country Studies, Vol 2, No.11.

Sinha, S., editor, (1998), 'Microcredit: impact, targeting and sustainability.' IDS Bulletin, 29(4), 1-11, October .

The Case of Micro and Small Women Business Entrepreneurs in Tanzania."'Tundui C. and Tundui H. (2013) "Microcredit, Micro Enterprising and Repayment Myth American Journal of Business and Management Vol. 2, No. 1 pp. 20-30.

Verhelle, C. and Berlage, L. (2003).Determinants of Microfinance Group Performance: An Empirical Analysis of Self-help Groups in India, Department of Economics, Katholic University Leuven, Belgium.

Vigano, L. (1993). A credit-scoring model for development banks: An African case study. Savings and Development, 17(4), pp 441\{482\}.

WoldayAmha, (2003).Micro Finance in Ethiopian Performance, Challenges and the Role in Poverty Reduction: AEMFI, Occasional Paper No.7.

World Bank (2005).How to make Micro and Rural Finance in Ethiopia More Sustainable, Africa Regional Financial Sector, Internal Draft Note (Schmidt).

World Bank (2005b).Ethiopia, Well-Being and Poverty in Ethiopia, The Role of Agriculture and Agency.

World Bank Financial Sector Capacity Building Project (2006c) Project Appraisal Document Report No 36272 ET.

William C. (Bill) Deegan, Sr. Richards (2007) .Collage of Business, state University of West Georgia. ZenaLemat Bank (2009) no 45 http://www.dbe.com.et.

Wongnaa C. A. and Awunyo-Vitor D. (2013). "Factors affecting loan repayment performance among Yam farmers in the Sene district, Ghana." Agris on-line Papers in Economics and Informatics Vol. No. 2.

Yaron, J. (1994).what makes rural finance institutions successful? The World Bank Research Observer, 9(1):497 